\title{
Financial Deepening and Economic Development in MENA Countries: Empirical Evidence from the Advanced Panel Method
}

\author{
Şerife Özşahin ${ }^{1} \&$ Doğan Uysal ${ }^{2}$ \\ ${ }^{1}$ Department of Economics, Necmettin Erbakan University, Konya, Turkey \\ ${ }^{2}$ Department of Economics, Celal Bayar University, Manisa, Turkey \\ Correspondence: Şerife Özşahin, Necmettin Erbakan University, Department of Economics, Konya, Turkey. \\ E-mail: sozsahin@konya.edu.tr
}

Received: February 5, 2017

Accepted: March 11, 2017

Online Published: March 20, 2017

doi:10.5539/ijef.v9n4p152

URL: https://doi.org/10.5539/ijef.v9n4p152

\begin{abstract}
This study analyses the effect of financial deepening on economic development in 12 MENA countries for the period between 2000 and 2014. Using three financial deepening indicators which are widely used in the literature, an econometric analysis was conducted through co-integration and estimation methods which take cross-sectional dependence into account. A long-term relationship between variables was revealed with Westerlund (2008) Durbin-Hausman panel co-integration test, and then, long-term coefficients were obtained using Pesaran (2006) CCE (Common Correlated Errors) estimator. Empirical findings point to a positive relationship between financial deepening indicators - domestic credit to private sector, domestic credit provided by private sector, and liquid liabilities of the financial system ratio - and economic development. With this study, it was shown that the domestic credit to private sector causes economic growth for five countries, domestic credit provided by financial sector causes economic growth for one country, and liquid liabilities of the financial system causes economic growth for four countries.
\end{abstract}

Keywords: financial deepening, economic growth, panel co-integration, McKinnon-Shaw hypothesis, MENA countries

\section{Introduction}

With the influence of Keynesian and Neo-classical theories, low interest rates were a recommended policy in order to increase investment and economic growth until the early 1970s. The reasons why this policy was preferred by governments are that it gives governments the chance to keep resource distribution under control and to finance public sector deficits with low cost (Collier \& Mayer, 1989, p. 6). These policies which are applied as interest rate ceilings, high reserve requirement on bank deposits and preferential credit allocation and which prevent the development of financial sector were called financial repression policies by McKinnon (McKinnon, 1989, p. 29).

Keeping interest rates negative or at low levels through financial repression policies has two negative effects on the economy. The first one is that low interest rates prevent financial deepening by decreasing saving and the amount of loanable funds in the financial system. The second negative effect is the ineffective distribution of resources that could be transferred to investment since banks use their own discretion in credit allocation (Andersen \& Tarp, 2003). McKinnon (1973) and Shaw (1973) are the first to argue that financial repression policies are to be abandoned because of such negative effects (Molho, 1986, p. 90).

This study investigates financial deepening and economic development nexus in MENA countries using advanced panel methods which take cross-sectional dependency into consideration. In this respect, theoretical explanations will be given following the introduction. The third section will present the studies that have researched the relationship between financial deepening and economic development within the context of MENA countries. In the fourth section, the data set and data sources used for empirical analysis and econometric method will be explained. Following the fifth section in which the findings obtained through panel co-integration test, parameter estimation and causality methods are interpreted, the study will be end with the conclusion section.

\section{Theoretical Framework}

Although studies exploring the relationship between financial and economic development date back to as early 
as the beginning of the 20th century, empirical studies started to increase after the 1980s. The evidences from empirical studies which examine the importance of finance sector for economic development can be grouped under three headings. The first one is the view that finance sector has a vital importance for economic growth (Schumpeter, 1911; Goldsmith, 1969; McKinnon, 1973; Shaw, 1973; Fry, 1978, 1988; Bencivenga \& Smith, 1991; King \& Levine, 1993a, b). The second view by Robinson (1952) and Lucas (1988) puts forward that financial matters are not very significant for economic growth and financial development only follows growth. The third view, as stated by VanWijnbergen (1983), Taylor (1983), Kohsaka (1984) and Buffie (1984), suggests that financial development may have negative effects on growth (Xu, 2000, p. 331).

Walter Bagehot (1873) and Joseph A. Schumpeter (1911), who examined the influence of banking sector on national income and Joan Robinson (1952), who states that economic growth lead to a demand for financial services, are the first scholars who explained the finance and growth interaction (Tsuru, 2000, p. 5). Schumpeter (1911) points out that a properly functioning banking system encourages technological innovation by providing resources for entrepreneurs to actualize their projects. According to all these studies, economic growth creates demand for financial transactions and financial system meets these demands (Levine, 1996, p. 1).

While Schumpeter (1911), McKinnon (1973) and Shaw (1973) emphasize the positive effects of financial development on growth, they do not explain how and through which channels this interaction will occur. Levine (1997) answers the question of how financial services will affect economic growth by taking the function of the financial sector into account. These functions can be summarized as making good and service exchange in financial system easier, enabling mobilization of savings, supervision of administrators, resource allocation and easing risk management (Levine, 1997, p. 691).

Besides, Gerschenkron (1962) emphasizes that a weak banking sector will bring along economic underdevelopment and that banking sector will affect the level of economic growth as it provides capital and enterprise input for industrialization (Eschenbach, 2004, p. 2). Contrary to the views which argue that financial development has a positive effect on growth, Lucas (1988) maintained that financial issues are attached too much importance for economic growth and that the effect of financial development on economic growth is limited (Lucas, 1988, p. 6).

Patrick (1966) was the one who explained the relationship between financial development and economic growth with respect to causality. Patrick (1966) explained the causality relationship between financial development and economic growth as demand-following and supply-leading. Demand-following analysis states that growth leads to development in financial system and low growth rate is a reflection of low demand for financial services (Patrick, 1966, pp. 174-175). Supply-leading approach, on the other hand, maintains that development in financial system will lead to economic growth and transferring scarce resources from savers to investors will increase economic growth (Patrick, 1966, pp. 175-176).

During the 1970s, the intervention of governments in financial systems with interest rate ceilings and price controls are called financial repression policies by McKinnon (1973), Shaw (1973) and Fry (1988) and have been intensively criticized due to their negative effects. Critics pointed out that the financial repression policies would prevent the development of banking sector and financial deepening, and the liberalization of financial markets was offered as a solution for economic development (Eschenbach, 2004, p. 1).

As of the 1990s, endogenous growth literature was extensively utilized in theoretical explanations that highlighted the positive link between financial system and growth (Eschenbach, 2004, pp. 1-2). Although the link between finance and economic growth was discussed in many studies, the discussions on this issue are generally summarized around two points. While the first of these two points is about whether developments in financial system are the result of economic growth, the second point is mostly related with how financial development affects economic growth (Acaravc1 et al., 2007, p. 30).

As a response to discussions on the second point which concerns how financial development affects economic growth, Bencivenga and Smith (1993) and Saint-Paul (1992) state that better risk allocation with the development of financial institutions will contribute to economic growth. On the other hand, Diamond (1984), Greenwood and Jovanovich (1990), and King and Levine (1993b) emphasize that financial intermediation is more efficient in collecting data than individual investors and thus increases growth.

\section{Literature Review}

Theoretical explanations about the relationship between financial development and economic growth state that a developed financial system will increase financial efficiency and financial deepening by decreasing information cost and transactions costs. Funds which are directed to the best investment projects as a result of the mobility of 
savings enable risk diversification. In a well-functioning financial system, better distribution of resources will increase economic growth by contributing to capital accumulation (Creane et al., 2004, p. 4).

Although the linkage between financial development and economic growth was examined in different countries, time slots and methods in the literature, when the findings are examined, it is seen that there is not a general consensus on this issue. The most important reason why there are few studies dealing with the relationship between economic development and financial deepening in the context of MENA countries is that data from these countries is not adequate. Some empirical studies on this relationship for MENA countries and the findings are summarized below.

Darrat (1999) used the Granger causality test in three MENA countries- Saudi Arabia, Turkey and United Arabic Emirates- to empirically research the importance of financial deepening for economic growth. Although the findings obtained varied along the indicators of financial deepening and countries, they revealed that financial deepening is necessary for economic growth.

Darrat and Haj (2002) sought to model the effect of financial development on economic growth volatility for the period between 1970 and 1999 for four MENA countries (Egypt, Jordan, Saudi Arabia, and Tunisia) through GARCH and Error Correction Mechanism. The findings of this study indicate the existence of a long-term relationship between financial deepening and economic growth rate for these four MENA countries. Also, it is understood that there is a strong relationship between development in financial markets and the long-term growth rates in MENA countries.

Archy (2004) studied the effect of financial development on personal saving, investment and economic growth in five MENA countries (Egypt, Jordan, Morocco, Tunisia and Turkey) by using the panel data technique because of limited data concerning the period between 1970 and 1998. The most significant empirical finding of the study is that there is a negative and statistically insignificant relationship between financial development and economic growth. Besides, the financial deepening indicators used in the study failed to explain the growth rates in these five MENA countries.

Boulila and Trabelsi (2004) tried to explain the causality between financial development and economic growth in MENA countries for the years between 1960 and 2002. The study revealed causality from real sector to financial sector and found some scant evidence that financial sector would lead to long-term growth.

Abu-Bader and Abu-Qarn (2006) applied the Granger causality test with co-integration and vector error-correction models for different periods from 1960 to 2004 in five MENA countries (Algeria, Egypt, Morocco, Syria and Tunisia) by using four different financial development indicators. Empirical results indicated scant evidence for the existence of a long-term relationship between financial development and economic growth. Another important finding of the study is that demand-following approach which maintains that development in finance sector will lead to economic growth is not valid for these five countries.

Al-Zubi et al. (2006), who examined the relationship between financial development and economic growth in 11 Arab countries in the period between 1980 and 2001, followed the model utilized in Levine's study (1997). The results of the analysis indicated that the financial indicators used in the study are statistically insignificant and do not affect economic growth. Besides, the findings that the public sector credits within the total domestic credit have statistically significant positive effect on economic growth indicate that public sector was dominant and financial sector was still less-developed in these 11 Arab countries.

Kar et al. (2010) carried out a study to determine the direction of causality between six different financial development indicators and economic growth by using panel causality method in the period between 1980 and 2007 for 15 MENA countries. The findings obtained from this study indicate that the direction of the causality between financial development indicators and economic growth is not clear.

Goaied and Sassi (2010), who examined the financial development-growth relationship using unbalanced panel data from 16 MENA countries for the period between 1962 and 2006, found that while the relationship between financial development and growth was negative in oil-exporting MENA countries, in countries without oil resources the direction of this relationship was positive and statistically insignificant. Furthermore, they revealed that the relationship between Islamic banking and economic growth was positive but weak in financial markets.

\section{Data Set and the Econometric Model}

This study utilized the panel co-integration method to test the relationship between financial deepening and economic growth and conducted an econometric analysis on MENA countries. Data for the period between 2000 and 2014 for 12 countries (Algeria, Bahrain, Egypt, Israel, Jordan, Kuwait, Oman, Qatar, Sudan, Tunisia, Turkey and Yemen) was compiled from World Bank World Development Indicator (2015) database. The econometric 
analysis was conducted via the EViews 8 and Gauss 10 software programs.

Three variables that are widely used in empirical research to model the different definitions of financial deepening were used in this study. The first of these variables is the ratio of liquid liabilities of the financial system, which is the most comprehensive measure of financial deepening. A high ratio refers to a higher level of deepening in the financial system and is mostly related to the function of financial markets to carry out financial transactions rather than to the function of transferring savings to investors. While the ratio of domestic credits to Gross Domestic Product (GDP) is the second indicator, the third indicator is the ratio of private sector credits to GDP. A high ratio of private sector credits to GDP indicates that banking sector and private sector have more influence on economy. Similarly, the ratio of domestic credits to GDP is an indicator of high level of domestic investment and financial system development. The study used GDP per capita values for each country to represent the economic growth variable. Explanations for the variables used in the econometric analysis and data sources are given in Table 1.

Table 1. The definition of the variables and data sources

\begin{tabular}{lll}
\hline Variable & Series & Data Source \\
\hline LPRIV_CREDIT & Domestic credit to private sector (\% of GDP) & World Bank, WDI \\
LFIN_CREDIT & Domestic credit provided by financial sector (\% of GDP) & World Bank, WDI \\
LLIQ_LIA & The ratio of liquid liabilities of the financial system as \% of GDP & International Monetary Fund, IFS. \\
LGDP & GDP per capita (constant 2010 US\$) & World Bank WDI \\
LGOV & General government final consumption expenditure (\% of GDP) & World Bank WDI \\
LTRADE & The total value of imports and exports of goods and services (\% of GDP) & World Bank WDI \\
LINF & Consumer price index $(2010=100)$ & World Bank, WDI \\
\hline
\end{tabular}

As in the study of Hassan et al. (2010), the ratio of trade to GDP and the ratio of general government final consumption expenditure to GDP variables were added in the study to represent the size of the real sector and the weight of financial sector in economy. To represent price movements, consumer price index was also included in the study as another control variable.

The hypothesized models are given in Equations 1, 2 and 3.

$$
\begin{aligned}
& \text { MODEL I: } L G D P=\beta_{0}+\beta_{1} L P R I V_{-} C R E D I T+\beta_{2} L T R A D E+\beta_{3} L G O V+\beta_{4} L I N F+\varepsilon \\
& \text { MODEL II: } L G D P=\beta_{0}+\beta_{1} L F I N_{-} C R E D I T+\beta_{2} L T R A D E+\beta_{3} L G O V+\beta_{4} L I N F+\varepsilon \\
& \text { MODEL III: } L G D P=\beta_{0}+\beta_{1} L L I Q \_L I A+\beta_{2} L T R A D E+\beta_{3} L G O V+\beta_{4} L I N F+\varepsilon
\end{aligned}
$$

Panel data analysis, which enables the use of a few countries in the same model, has widely been used in recent applied studies. It is a favorable analysis method as it allows for the integrated use of time series and cross-section data. Baltagi (2001) listed the advantages of the panel method as follows (Baltagi, 2001, pp. 37-38):

- The panel data analysis enables a better control of intergroup heterogeneity effects.

- It helps decrease multi-collinearity among explanatory variables.

- It increases the efficiency of econometric estimators with these advantages.

With panel data analysis, the methods to be used to determine the stationary of the variables, the detection of a long-term relationship and causality vary based on the presence of cross-sectional dependence. Thus, in panel data analysis, it is necessary first to explore the presence of cross-sectional dependence among the countries in the panel and then to continue with unit root, co-integration and causality analysis with the methods appropriate for the result obtained earlier.

\section{Methodology and Empirical Findings}

In the empirical analysis which was conducted to reveal the effect of financial deepening on economic development in 12 MENA countries in the period between 2000 and 2014, first whether a shock in a country in the panel will affect the other countries was tested through cross-sectional dependence tests. Unit root, co-integration and causality methods to be used in the following stages were determined based on the results of cross-section dependence test.

\subsection{Cross-sectional Dependence and Homogeneity Tests}

The presence of cross-sectional dependence in each series for the 12 countries was researched with the Pesaran 
(2004) $C D_{L M 2}$ test and Pesaran et al (2008) Bias-adjusted CD test considering the fact that the time frame in the study is larger than cross-section. It was shown with the Pesaran (2004) $C D_{L M 2}$ test that time frame as well as cross-section can take high values $(\mathrm{T} \rightarrow \infty$ and $\mathrm{N} \rightarrow \infty)$ as in Eq.(4):

$$
C D_{L M 2}=\sqrt{\frac{1}{N(N-1)}} \sum_{i=1}^{N-1} \sum_{j=i+1}^{N}\left(T \hat{\rho}_{i j}^{2}-1\right)
$$

Equation 2 calculates the correlation coefficient between the residuals obtained with $\hat{\rho}_{i j}^{2}$ least square estimator. In this method, the null hypothesis claims that there is no cross-sectional dependence among the panel units, while the alternative hypothesis points to cross-sectional dependence among the panel units.

$H_{0}$ : There is no cross - sectional dependence among the countries in the panel.

$H_{1}$ :There is cross - sectional dependence among the countries in the panel.

For big panels in which time frame as well as cross-section takes high values, Pesaran et al. (2008) developed bias-adjusted LM statistics as shown in Equation 5 (Pesaran et al., 2008, p. 108).

$$
L M_{a d j}=\sqrt{\frac{2}{N(N-1)}} \sum_{i=1}^{N-1} \sum_{j=i+1}^{N} \frac{(T-k) \hat{\rho}_{i j}^{2}-\mu_{T i j}}{\vartheta_{T i j}}
$$

To determine the presence of cross-sectional dependence among the countries in the panel, or in other words, to accept the null hypothesis with the Pesaran (2004) $C D_{L M 2}$ test or the Pesaran et al. (2008) bias-adjusted CD test, the obtained statistics must be at $95 \%$ significance level and less than 0.05 . Cross-sectional dependence test results for each model to be estimated in this study are given in Table 2.

\begin{tabular}{|c|c|c|c|c|c|c|}
\hline & \multicolumn{2}{|c|}{ Model I } & \multicolumn{2}{|c|}{ MODEL II } & \multicolumn{2}{|c|}{ MODEL III } \\
\hline & Statistics & Probability & Statistics & Probability & Statistics & Probability \\
\hline$C D_{L M 2}$ (Pesaran, 2004) & 17.137 & 0.000 & 14.155 & 0.000 & 12.103 & 0.000 \\
\hline Bias-adjusted CD test (Pesaran et al., 2008) & 10.025 & 0.000 & 9.500 & 0.000 & 9.648 & 0.000 \\
\hline$\tilde{\Delta}$ (Pesaran \& Yamagata, 2008) & -0.746 & 0.772 & -0.4279 & 0.665 & -0.330 & 0.629 \\
\hline$\tilde{\Delta}_{a d j .}$ (Pesaran \& Yamagata 2008) & -0.944 & 0.827 & -0.5412 & 0.705 & -0.417 & 0.661 \\
\hline
\end{tabular}

Table 2. Cross-sectional dependence and homogeneity tests results

As seen in Table 2, since the probability values of the $C D_{L M 2}$ and bias-adjusted CD tests are at $95 \%$ significance level and lower than 0.05 in three models, the null hypothesis which claims that there is no cross-sectional dependence is rejected, and thus the alternative hypothesis is accepted. In each of the three models, there is cross-sectional dependence among the countries in the panel.

In panel data analysis, another important pre-analysis that needs to be carried out in addition to cross-sectional dependence is the homogeneity test. The Delta test $(\tilde{\Delta})$ developed by Pesaran and Yamagata (2008) was used to determine the homogeneous and heterogeneous structure of the coefficients of the countries in the long-term equation. When the number of countries in the panel is low, $\tilde{\Delta}_{\text {adj }}$. statistics, and when the panel is big, $\tilde{\Delta}$. statistics produce more meaningful results. The calculations to obtain $\tilde{\Delta}_{a d j}$ and $\tilde{\Delta}$. statistics are shown in Equation 6 and 7 (Pesaran \& Yamagata, 2008, p. 57).

$$
\begin{gathered}
\hat{\Delta}=\sqrt{N}\left(\frac{N^{-1} \tilde{S}-k}{\sqrt{2 k}}\right) \\
\tilde{\Delta}_{a d j .}=\sqrt{N}\left(\frac{N^{-1} \tilde{S}-E\left(\tilde{Z}_{i T}\right.}{\sqrt{\operatorname{var} \tilde{Z}_{i T}}}\right)
\end{gathered}
$$

Delta homogeneity test shows that country coefficients are homogeneous in the null hypothesis, but heterogeneous in the alternative hypothesis. As the probability value is at $95 \%$ significance level and higher than 0.05 , the null hypothesis cannot be rejected and the country coefficients are homogeneous.

$H_{0}$ : Slope coefficients have homogeneity.

$H_{1}$ : Slope coefficients have heterogeneity. 
When the homogeneity test results given in Table 2 are considered, it can be stated that as the probability value for the three models is above 0.05 , slope coefficients of countries are homogenous. Based on these findings, it can be concluded that there is cross-sectional dependence in the panel that underlies our study and country coefficients are homogeneous. The analyses continued with Hadri and Kurozumi (2012) unit root test, which takes cross-sectional dependence into account for stationary analysis.

\subsection{Hadri and Kurozumi Unit Root Test}

Hadri and Kurozumi (2012) unit root test examines stationary with the lag length obtained through the CADF test developed by Pesaran (2007). In the null hypothesis it is stated that the series does not have unit root and is stationary, while in the alternative hypothesis it is claimed that the series has unit root. The CADF test makes calculations for each country and produces a common CIPS value for the panel, while Hadri-Kurozumi test gives a single result for the whole panel.

Hadri-Kurozumi test makes two different long-term variance estimation as $Z_{A}^{S P C}$ and $Z_{A}^{L A} . Z_{A}^{S P C}$ yields more meaningful results when there is cross-sectional dependence, while $Z_{A}^{L A}$ results are more meaningful when there is cross-sectional independence.

Table 3. Hadri and Kurozumi (2012) unit root test results

\begin{tabular}{lcccc}
\hline Variable & $\begin{array}{c}Z_{A}^{S P C} \\
\text { Constant }\end{array}$ & $\begin{array}{c}Z_{A}^{L A} \\
\text { Constant }\end{array}$ & $\begin{array}{c}Z_{A}^{S P C} \\
\text { Constant-Trend }\end{array}$ & $\begin{array}{c}Z_{A}^{L A} \\
\text { Constant-Trend }\end{array}$ \\
\hline LPRIV_CREDIT & $0.16(0.43)$ & $24.41(0.00)$ & $6.01(0.00)$ & $28.89(0.00)$ \\
LFIN_CREDIT & $6.16(0.00)$ & $14.7(0.00)$ & $-0.1(0.50)$ & $4.59(0.00)$ \\
LLIQ_LIA & $-1.25(0.89)$ & $-1.39(0.91)$ & $0.88(0.18)$ & $14.61(0.00)$ \\
LGDP & $1.92(0.02)$ & $18.33(0.00)$ & $2.93(0.04)$ & $12.88(0.00)$ \\
LGOV & $2.72(0.00)$ & $0.19(0.42)$ & $0.14(0.44)$ & $4.40(0.00)$ \\
LTRADE & $1.16(0.12)$ & $3.54(0.00)$ & $-1.77(.96)$ & $-2.19(0.98)$ \\
LINF & $-0.15(0.56)$ & $26.9(0.00)$ & $1.61(0.05)$ & $75.9(0.00)$ \\
\hline
\end{tabular}

$L G D P$, which is the common dependent variable of the three models to be estimated to determine the effect of financial deepening on economic development in this study, indicates based on the $Z_{A}^{S P C}$ and $Z_{A}^{L A}$ statistics for both the constant and the constant-trend model that the null hypothesis will be rejected at $95 \%$ significance level and the series is not stationary at this level. The results for the LPRIV_CREDIT variable, which is the first financial deepening indicator, reveal that this series has unit root other than the $Z_{A}^{S P C}$ statistics for the constant model, meaning that the null hypothesis will strongly be rejected. The results for the other financial deepening indicator, LFIN_CREDIT variable, show that this series has unit root at $99 \%$ significance level according to both the $Z_{A}^{S P C}$ and $Z_{A}^{L A}$ statistics for the constant model and the $Z_{A}^{L A}$ statistics for the trend model.

\subsection{Westerlund (2008) Durbin-Hausman Co-Integration Test}

Westerlund (2008) Durbin-Hausman Co-Integration test was used to detect the presence of a long-term relationship between financial deepening indicators and economic growth. According to this method, while researching the presence of long-term relationship among the series with cross-section dependence, dependent variable must be stationary at first difference, whereas there is no such condition for independent variables (Westerlund, 2008, p. 205).

$$
\begin{aligned}
D H_{g} & =\sum_{i=1}^{n} \hat{S}_{i}\left(\tilde{\theta}_{i}-\hat{\theta}_{i}\right)^{2} \sum_{t=2}^{T} \hat{e}^{2}{ }_{i t-1} \\
D H_{p} & =\hat{S}_{n}(\tilde{\theta}-\hat{\theta})^{2} \sum_{i=1}^{n} \sum_{t=2}^{T} \hat{e}^{2}{ }_{i t-1}
\end{aligned}
$$

The Durbin-Hausman test calculates $D H_{g}$ for the group (Equation 8) and $D H_{p}$ for the panel (Equation 9). For both statistics, it is stated that there is no co-integration among the variables in the null hypothesis. According to panel statistics $D H_{p}$, the rejection of the null hypothesis means co-integration for the whole panel. According to the group statistics $D H_{g}$, on the other hand, the rejection of the null hypothesis refers to a long-term relationship in some of the countries in the panel (Westerlund, 2008, p. 203).

For panel statistics

$H_{0}$ : No cointegration

$H_{1}$ : Cointegration for all panel
For group statistics

$H_{0}$ : No cointegration

$H_{1}$ : Cointegration for some countries 
Based on this method, the calculated $D H_{p}$ panel statistics and $D H_{g}$ group statistics must be higher than the critical table value to reject the null hypothesis and to reach the conclusion that there is co-integration among the variables (Westerlund, 2008, p. 204). The Durbin-Hausman co-integration test results are given in Table 4.

Table 4: Westerlund (2008) Durbin-Hausman co-integration test results

\begin{tabular}{lll}
\hline & $D H_{g}$ group statistics & $D H_{p}$ panel statistics \\
\hline Model I & 8.214 & -0.919 \\
Model II & 3.929 & -0.319 \\
Model III & 5.769 & -0.779 \\
Critical Values & & \\
$\% 1$ & 2.33 & 2.33 \\
$\% 5$ & 1.645 & 1.645 \\
$\% 10$ & 1.28 & 1.28 \\
\hline
\end{tabular}

Durbin-Hausman group statistics given in Table 4 show that for models 1,2 and 3, the null hypothesis was rejected at $99 \%$ significance level and thus, there is a long-term relationship in some countries. Based on this finding, it can be stated that there is co-integration between financial deepening indicators and economic growth in some country groups in the panel. However, when Durbin-Hausman panel statistics is examined, it is seen that the null hypothesis is accepted for all models and that there is no indication of a long-term relationship in the whole panel.

\subsection{The Estimation of Long-Run Parameters}

As the co-integration methods indicate a long-term relationship among the variables, long-term coefficients must be obtained with parameter estimation as well. For this purpose, long-term equations expressed in Equations 1, 2 and 3 were estimated with the Pesaran (2006) Common Correlated Effects (CCE) method. The linear panel data model, in which $i$ indicates cross-section unit and $\mathrm{t}$ represents time, can be written as in Equation 10.

$$
\begin{gathered}
Y_{i t}=\alpha_{i}^{\prime} d_{t}+\beta_{i}^{\prime} x_{i t}+e_{i t} \\
e_{i t}=\gamma_{i}^{\prime} f_{t}+\epsilon_{i t}
\end{gathered}
$$

$d_{t}$ is the $n x 1$ vector of the common effects observed as constant term and seasonal dummies, while $x_{i t}$ is the observed $k x 1$ vector of the individual estimators of the $i$ cross-section unit at $t$ time. In the error term equation in Eq. (11), $f_{t}$ represents the $m x 1$ vector of unobservable common effects, and $\epsilon_{i t}$ indicates individual errors (Pesaran, 2006, p. 971). This method is effective as it makes calculations through a model in which the observed regressors are extended with the cross-section mean of the dependent variable and a individual regressor. Monte Carlo calculations show that CCE estimator yields satisfactory results even with a small sample and in a short time frame (Pesaran, 2006, p. 967).

\begin{tabular}{|c|c|c|c|c|c|c|}
\hline & \multicolumn{2}{|c|}{ MODEL I } & \multicolumn{2}{|c|}{ MODEL II } & \multicolumn{2}{|c|}{ MODEL III } \\
\hline & Coefficient & t-stat & Coefficient & t-stat & Coefficient & t-stat \\
\hline LPRIV_CREDIT & 0.058 & 0.93 & & & & \\
\hline$L F I N \_C R E D I T$ & & & 0.015 & 0.25 & & \\
\hline$L L I Q \_L I A$ & & & & & 0.109 & 1.14 \\
\hline LTRADE & $0.075^{*}$ & 1.75 & 0.091 & 1.26 & 0.029 & 0.36 \\
\hline LGOV & $-0.274 * * *$ & -2.90 & $-0.166^{*}$ & -1.71 & $-0.266^{* * *}$ & -2.74 \\
\hline$L I N F$ & $0.218^{* *}$ & 1.92 & $0.274 * * *$ & 2.83 & $0.217 * * *$ & 2.39 \\
\hline Constant & $8.277 * * *$ & 8.71 & $7.81 * * *$ & 7.43 & $8.233 * * *$ & 6.62 \\
\hline
\end{tabular}

Table 5. Pesaran (2006) CCE estimation results

Note. $* * *$, and $* * *$ indicate rejection of the null hypothesis at the 10,5 , and 1 percent levels of significance, respectively.

Long-term coefficients for the three models estimated to determine the relationship between financial deepening and economic growth are given in Table 5. According to these results, although each financial deepening indicator affects economic growth positively, the results are not statistically significant. According to the results of the first model in which private sector domestic credit is the financial deepening indicator, openness rate and inflation rate affect economic growth positively at $10 \%$ and $5 \%$ significance level, respectively. In the same 
model, the effect of government final expenditure on economic development is negative and statistically significant. Similar results were observed in the other two models. Consumer price index in the models where both the volume of credit given by the finance sector and liquid liabilities variables are indicators of financial deepening affect economic development positively at $1 \%$ significance level, while the effect of government final expenditure on economic development is negative and statistically significant. According to these findings, although the effect of financial deepening on economic development is positive, but statistically insignificant, the effect of government final expenditure is statistically significant. These results indicate that in the 12 MENA countries in the sample, public sector has a larger share in the financial system compared to the private sector.

\subsection{Emirmahmutoğlu and Köse Causality Analysis}

The findings from the co-integration test revealed that there is a long-term relationship among the variables, which also indicates the possibility of causality. Granger VECM method is used to detect causality when variables are co-integrated. However, before this method is applied, some pre-tests must be conducted to reveal the level of stationary and the co-integration relationship. Similar to the Toda and Yamamoto (1995) causality test, which does not require these pre-tests in time-series analysis, Emirmahmutoğlu and Köse (2011) developed a method to be used in the panel data analysis. In this method, which can also be used when cross-sectional dependence is present, it is not necessary for the series to have the same level of steadiness and to be cointegrated (Emirmahmutoğlu \& Köse, 2011, p. 870).

The panel VAR model with the variable $\mathrm{P}$ can be written as in Eq. (10):

$$
Z_{i, t}=\mu_{i}+A_{i 1} Z_{i, t-1}+\cdots+A_{i k_{i}} Z_{i, t-k_{i}}+u_{i t}
$$

In this equation, $i$ represents cross-section units, $\mathrm{t}$ represents time, and $\mu_{i}$ represents fixed-effects vector with $\mathrm{p}$ dimension. This method allows for variations in $k_{i}$ lag length for each country (Emirmahmutoğlu \& Köse, 2011, p. 871). To give ${d \max _{i}}_{i}$ is the maximum integration levels of variables, $k_{i}+\operatorname{dmax}_{i}$ lagged VAR model in heterogeneous panel can be written as shown in Eq. (11) and (12). Eq. (11) is estimated for causality from X to Y, while Eq. (12) is estimated for causality from Y to X (Emirmahmutoğlu \& Köse, 2011, pp. 871-872).

$$
\begin{aligned}
& X_{i, t}=\mu_{i}^{x}+\sum_{j=1}^{k_{i}+d \max _{i}} A_{11, i j} X_{i, t-j}+\sum_{j=1}^{k_{i}+d \max _{i}} A_{12, i j} Y_{i, t-j}+u_{i t}^{X} \\
& Y_{i, t}=\mu_{i}^{Y}+\sum_{j=1}^{k_{i}+d \max _{i}} A_{21, i j} X_{i, t-j}+\sum_{j=1}^{k_{i}+d \max _{i}} A_{22, i j} Y_{i, t-j}+u_{i t}^{Y}
\end{aligned}
$$

The Fisher statistics was calculated to choose between the null hypothesis which states that there is no causality and the alternative hypothesis which suggests causality.

$$
\lambda=-2 \sum_{i=1}^{N} \ln \left(p_{i}\right) \quad i=1,2,3, \ldots N
$$

In the Fisher statistics expressed in Eq. (13), $p_{i}$ is the probability value of the Wald statistics for $i$ cross-section unit. This statistics has the chi-square distribution at $2 \mathrm{~N}$ degree of freedom (Emirmahmutoğlu \& Köse, 2011, p. 872). Table 6 gives the results of the Emirmahmutoğlu and Köse (2011) causality test pertaining to economic development, which is the dependent variable in the study, and the financial deepening indicators. As the results in the table show, while the private sector credit, which is the first financial deepening indicator, is the reason behind economic growth in five of the countries in the sample, in three countries economic growth lead to private sector credits.

Table 6. Emirmahmutoğlu and Köse (2011) causality test results

\begin{tabular}{lllllll}
\hline Country & $\begin{array}{l}\text { LPRIV_CREDIT } \\
\rightarrow \text { LGDP }\end{array}$ & $\begin{array}{c}\text { LGDP } \rightarrow \\
\text { LPRIV_CREDIT }\end{array}$ & $\begin{array}{l}\text { LFIN_CREDIT } \\
\rightarrow \text { LGDP }\end{array}$ & $\begin{array}{l}\text { LGD } \rightarrow \\
\text { LFIN_CREDIT }\end{array}$ & $\begin{array}{l}\text { LLIQ_LIA } \\
\rightarrow \text { LGDP }\end{array}$ & $\begin{array}{c}\text { LGDP } \rightarrow \\
\text { LLIQ_LIA }\end{array}$ \\
\hline Algeria & 7.76 & 4.39 & $17.6^{* * *}$ & 1.59 & 0.00 & 1.35 \\
Bahrain & 4.51 & 0.29 & 2.34 & 0.13 & 0.98 & 4.87 \\
Egypt & 6.75 & $70.1^{* * *}$ & 1.28 & 0.80 & 1.44 & $5.34^{*}$ \\
Israel & 0.30 & $3.45^{*}$ & 2.59 & 1.27 & $28.4^{* * *}$ & $13.8^{* * *}$ \\
Jordan & 0.52 & 2.68 & 6.09 & $10.7^{*}$ & 2.78 & $12.0^{* * *}$ \\
Kuwait & 2.74 & $33.3^{* * *}$ & 2.30 & 0.49 & 0.85 & $4.48^{*}$ \\
Oman & $18.7^{* * *}$ & 0.84 & 1.76 & 0.04 & 2.13 & $14.6^{* * *}$ \\
Qatar & 0.85 & 4.86 & 1.21 & 1.13 & $106^{* * *}$ & 2.06 \\
Sudan & $57.5^{* * *}$ & 8.05 & 2.56 & 0.51 & $81.2^{* * *}$ & $6.87^{*}$ \\
Tunisia & $14.4^{* *}$ & 1.83 & 0.56 & 0.95 & 0.58 & 0.38 \\
Turkey & $12.3^{*}$ & 6.56 & 2.31 & 1.22 & $12.9^{* * *}$ & 5.36 \\
Yemen & $23.6^{* * *}$ & 1.16 & 0.21 & 0.00 & 0.01 & 0.24
\end{tabular}


Causality test results for the relationship between domestic credit provided by financial sector- one of the financial deepening indicators- and economic growth can be seen in the fifth and sixth columns of Table 6 . According to these results, among 12 countries, only in Algeria domestic credit provided by financial sector is the reason for economic growth and only in Jordan economic growth is the reason behind domestic credit provided by financial sector. The third financial deepening indicator, the ratio of liquid liabilities of the financial system, leads to economic growth in four countries and is the result of growth in six countries.

\section{Conclusion}

This study examined the relationship between financial deepening and economic growth using data for 12 MENA countries from the period between 2000 and 2014. The most widely-used indicators in the literature to measure financial deepening are domestic credit to private sector to GDP, domestic credit provided by private sector, and the ratio of liquid liabilities of the financial system to GDP. In three different models in which each indicator represents financial deepening, the common dependent variable was GDP percapita, and common control variables were consumer price index, openness rate and government final expenditure to GDP. As there is cross-section dependence among the countries in the sample, econometric analysis was conducted with Hadri-Kurozumi (2012) unit root test, Westerlund (2008) Durbin-Hausman cointegration test, Pesaran (2006) CCE parameter estimator and Emirmahmutoğlu and Köse (2011) causality test.

Following the Hadri and Kurozumi (2012) unit root test results, which indicated that variables have different stationary levels, Westerlund (2008) co-integration test, which helps detect the long-term relationship among series that are statinary at different levels, was conducted. The Durbin-Hausman group test results of this method indicated that there is a long-term relationship between financial deepening and economic growth in some countries in the panel. Although the long-term coefficients obtained through Pesaran (2006) CCE estimator show that financial deepening indicators affect economic development positively, this effect is statistically insignificant. Despite this result, it was also found that government final expenditure has a statistically significant effect on economic growth, which indicates that public sector is more influential than finance sector in MENA countries. The causality results revealed that economic growth results from domestic credit provided by financial sector in five countries, from domestic credit provided by financial sector in one country, and from the ratio of liquid liabilities of the financial system in four countries. In other words, there is a one-way causality relationship from financial deepening indicators to economic growth in these countries.

\section{Acknowledgments}

This study benefited from the doctoral dissertation entitled "An Analysis of the Interaction Between Financial Liberalization and Economic Growth in Turkey with ARDL Method" accepted by Selcuk University, Institute of Social Sciences under the supervision of Assoc.Prof.Dr. Dogan Uysal.

\section{References}

Abu-Bader, S., \& Abu-Qarn, A. (2006). Financial development and economic growth nexus: Time series evidence from middle eastern and north african countries. Retrieved from http://mpra.ub.uni-muenchen.de/972/

Acaravc1, A., Öztürk, İ., \& Acaravc1, S. K. (2007). Finance-growth nexus: evidence from Turkey. International Research Journal of Finance and Economics, 11, 30-40. http://dx.doi.org/10.2139/ssrn.1401590

Achy, L. (2004). Financial liberalization, saving, investment and growth in MENA countries. Finance EconWPA No: 0411004. Retrieved from http://129.3.20.41/eps/fin/papers/0411/0411004.pdf

Al-Zubi, K., Al-Rjoub, S., \& Abu-Mharebe. (2006). Financial development and economic growth: A new empirical evidence from the MENA countries, 1989-2001. Applied Econometrics and International Development, 6(3), 137-150.

Andersen, T. B., \& Tarp, F. (2003). Financial liberalization, financial development and economic growth in LDCs. Journal of International Development, 15(2), 189-209. http://dx.doi.org/10.1002/jid.971

Bagehot, W. (1873). Lombard Street, a description of the money market. London.

Baltagi, B. H. (2001). Econometric analysis of panel data. NewYork: John Wiley.

Bencivenga, V. R., \& Smith, B. (1993). Some consequences of credit rationing in an endogenous growth model. Journal of Economic Dynamics and Control, 17, 97-122. http://dx.doi.org/10.1016/S0165-1889(06)80006-0

Bencivenga, V. R., \& Smith, B. D. (1991). Financial intermediation and endogenous growth. Review of Economic Studies, 58, 195-209. 
Boulila, G., \& Trabelsi, M. (2004). The causality issue in the finance and growth nexus: Empirical evidence from middle east and north african countries. Review of Middle East Economics and Finance, 2(2), 123-138.

Buffie, E. F. (1984). Financial repression, the new structualists and stabilization policy in semi-industrialized economics. Journal of Development Economics, 14(3), 305-322.

Collier, P., \& Mayer, C. (1989). The assessment: Financial liberalization, financial systems, and economic growth. Oxford Review of Economic Policy, 5(4), 1-12.

Creane, S., Goyal, R., Mobarak, M., \& Sab, R. (2004). Financial sector development in the middle east and north africa. IMF Working Paper. Paper No 04/201, Washington: International Monetary Fund.

Darrat, A. F. (1999). Are financial deepening and economic growth causally related? Another look at the evidence. International Economic Journal, 13(3), 19-35. http://dx.doi.org/10.1080/10168739900000002

Darrat, A. F., \& Haj, M. (2002). Economic fluctuations in mena: does financial market development matter? ERF 9th Annual Conference, Al-Sharja, United Arab Emirates, October 26-28, 2002.

Diamond, D. W. (1984). Financial intermediation and delegated monitoring. The Review of Economic Studies, 51(3), 393-414.

Emirmahmutoglu, F., \& Kose, N. (2011). Testing for granger causality in heterogeneous mixed panels. Economic Modelling, 28, 870-876. http://dx.doi.org/10.1016/j.econmod.2010.10.018

Eschenbach, F. (2004). Finance and growth: A survey of the theoretical and empirical literature. Tinbergen Institute Discussion Papers. Paper No: TI 2004-039/2.

Fry, M. (1978). Money and capital or financial deepening in economic development? Journal of Money Credit and Banking, 10(4), 464-475.

Fry, M. (1988). Money, interest and banking in economic development. Baltimore: Johns Hopkins University Press.

Gerschenkron, A. (1962). Economic backwardness in historical perspective: A book of essays. Cambridge: Harvard University Press.

Goaied, M., \& Sassi, S. (2010). Financial development and economic growth in the mena region: What about islamic banking development. financial and monetary. European Integration Group Workshop on Islamic Finance, March 17th, 2010, Strasbourg Business School. Retrieved from http://www.em-strasbourg.eu/docs/iw/papers/Goaied-Sassi.pdf

Goldsmith, R. W. (1969). Financial structure and development. New Haven, CT: Yale University Press.

Greenwood, J., \& Jovanovic, B. (1990). Financial development, growth and the distribution of income. Journal of Political Economy, 98(5), 1076-1107. http://dx.doi.org/10.1086/261720

Hadri, K., \& Kurozumi, E. (2012). A simple panel stationarity test in the presence of serial correlation and a common factor. Economics Letters, 115, 31-34. http://dx.doi.org/10.1016/j.econlet.2011.11.036

Hassan, K., Sanchez, B., \& Yu, J. (2010). Financial development and economic growth: New evidence from panel data. The Quarterly Review of Economic and Finance.

Kar, M., Nazlığlu, Ş., \& Ağır, H. (2011). Financial development and economic growth nexus in the mena countries: Bootstrap panel granger causality analysis. Economic Modelling, 28, 685-693. http://dx.doi.org/10.1016/j.econmod.2010.05.015

King, R. G., \& Levine, R. (1993a). Finance and growth: schumpeter might be right? The Quarterly Journal of Economics, 108(3), 717-737.

King, R. G., \& Levine, R. (1993b). Finance, entrepreneurship and growth: Theory and evidence. Journal of Monetary Economics, 32(3), 513-542.

Kohsaka, A. (1984). The high interest rate policy under financial repression. Developing Economies, 22(4), 419-452.

Levine, R. (1996). Financial development and economic growth: Views and agenda. Policy Research Working Paper Series 1678, The World Bank.

Levine, R. (1997). Financial development and economic growth: Views and agenda. Journal of Economic Literature, 35(2), 688-726.

Lucas, R. E. (1988). On the mechanics of economic development. Journal of Monetary Economics, 22(1), 3-42. 
http://dx.doi.org/10.1016/0304-3932(88)90168-7

McKinnon, R. I. (1973). Money and capital in economic development. Washington: Brookings Institution.

McKinnon, R. I. (1989). Financial liberalization and economic development: A reassessment of interest rate policies in asia and latin america. Oxford Review of Economic Policy, 5(4), 29-54.

Molho, L. (1986). Interest rate, savings and investment in developing countries: A re-examination of the mckinnon-shaw hypothesis. IMF Staff Papers, 33(1), 90-111. http://dx.doi.org/10.2307/3866923

Patrick, H. T. (1966). Financial development and economic growth in underdeveloped countries. Economic Development and Cultural Change, 14(2), 174-189.

Pesaran, M. H. (2004). General diagnostic tests for cross section dependence in panels. Cambridge Working Papers in Economics, No. 0435. Faculty of Economics, University of Cambridge.

Pesaran, M. H. (2006). Estimation and inference in large heterogeneous panels with multifactor error structure. Econometrica, 74, 967-1012.

Pesaran, M. H., \& Yamagata, T. (2008). Testing slope homogeneity in large panels. Journal of Econometrics, 142(1), 50-93. http://dx.doi.org/10.1016/j.jeconom.2007.05.010

Pesaran, M. H., Ullah, A., \& Yamagata, T. (2008). A bias-adjusted LM test of error cross-section independence. Econometrics Journal, 11, 105-127. http://dx.doi.org/10.1111/j.1368-423X.2007.00227.x

Peseran, M. H. (2007). A simple panel unit root tests in the presence of cross section dependency. Journal of Applied Econometrics, 22, 265-312. http://dx.doi.org/10.1002/jae.951

Robinson, J. (1952). The generalization of the general theory. In The Rate of Interest and Other Essays (pp. 67-142). Macmillan: London.

Saint-Paul, G. (1992). Technological choice, financial markets and economic development. European Economic Review, 36, 763-781.

Schumpeter, J. A. (1911). The theory of economic development. Cambridge: Harvard University Press.

Shaw, E. S. (1973). Financial deepening in economic development. NewYork: Oxford University Press.

Taylor, L. (1983). Structuralist macroeconomics: Applicable models for the third world. NewYork: Basic Books.

Tsuru, K. (2000). Finance and growth: Some theoretical considerations and a review of the empirical literature. OECD Economics Department, Working Papers, No:228. http://dx.doi.org/10.1787/307832384453

Van Wijnbergen, S. (1983). Credit policy, inflation and growth in a financially repressed economy. Journal of Development Economics, 13(1-2), 45-65.

Westerlund, J. (2008). Panel cointegration tests of the fisher effect. Journal of Applied Econometrics, 23, 193-233. http://dx.doi.org/10.1002/jae.967

Xu, Z. (2000). Financial development, Investment, and economic growth. Economic Inquiry, 38(8), 331-344. http://dx.doi.org/10.1111/j.1465-7295.2000.tb00021.x

\section{Copyrights}

Copyright for this article is retained by the author(s), with first publication rights granted to the journal.

This is an open-access article distributed under the terms and conditions of the Creative Commons Attribution license (http://creativecommons.org/licenses/by/4.0/). 